\title{
Now We Want Our Funk Cut: Janelle Monáe's Neo-Afrofuturism
}

\author{
Daylanne K. English and Alvin Kim
}

Multimedia conceptual artist Paul D. Miller (a.k.a. DJ Spooky/That Subliminal Kid) has recently argued that Afrofuturism is a thing of the past, a movement that, in his words, "wasn't digital enough ... [and] didn't have a core group of people with any kind of coherent message. It was conceptually open ended without any kind of narrative."1 Miller's assessment of past forms of Afrofuturism is certainly arguable, but contemporary singer, songwriter, dancer, performance artist, and self-proclaimed "funkstress" Janelle Monáe explodes any notion that Afrofuturism is no more. ${ }^{2}$ If we define Afrofuturism as African American cultural production and political theory that imagine less constrained black subjectivity in the future and that produce a profound critique of current social, racial, and economic orders, then there can be no doubt that Monáe stands at the center of a new form of Afrofuturism that she performs through what the liner notes from her EP Metropolis (inspired by Fritz Lang's classic 1927 film of the same name) term "cybersoul," a complex blend of multiple, often technologically mediated musical genres. ${ }^{3}$

Among those genres, funk stands out as Monáe's perhaps most sustained influence. As the website for Wondaland Arts Society, the Atlanta-based artists' collective of which Monáe is a founding member, states: "We believe there are only three forms of music: good music, bad music and funk." ${ }^{4}$ Monáe thereby honors, yet also expands upon, earlier forms of Afrofuturistic funk, most obviously that of George Clinton and Parliament-Funkadelic, who, starting in the 


\section{Daylanne K. English and Alvin Kim}

mid-1970s, famously imagined and performed for African American people a "Mothership Connection"-or, as they sang, "Time to move on light years in time ahead of our time / Free your mind to come fly with me on the mothership." "With their elaborate stage spectacles, including a landing by an immense spaceship and Clinton's emerging from it, P-Funk offered their audiences a powerful and playful narrative of transcendence and reclamation. Monáe offers a recorded and performed narrative of possible transcendence as well, yet that narrative is more "coherent," to use DJ Spooky's term, as well as even more explicitly political and inclusive than was Clinton and Parliament-Funkadelic's. Over the course of the last five years, with three albums, a number of videos, and many stage performances, Monáe has undertaken a musical, lyrical, visual, performative, and theoretical investigation into, and destabilization of, not only race and gender, but also sexuality, color, and class. She shows us new liberatory possibilities created by African American cultural production in concert with contemporary technological transformation: that is, neo-Afrofuturism. In the words of the Wondaland collective: "We believe songs are spaceships. We believe music is the weapon of the future. We believe books are stars."

On the other hand, Monáe also challenges DJ Spooky's confidence regarding the power of the digital and the technological. Her lyrics, in particular, suggest that pure optimism regarding technoculture understates its vulnerability to being shaped by commodity culture and by regressive notions of human subjectivity and categories of identity. Monáe is ever alert to the marketplace and her place within it, particularly as an African American woman with working-class roots, even as she exploits that marketplace in the name of future justice. Monáe thus avoids the pitfalls of what Madhu Dubey, following Fredric Jameson, terms postmodernism's "romance of the residual," in which African Americans and African American culture alone become somehow "exempt ... from the contingencies of the postmodern condition," standing always for "bodily presence, palpable reality, political intentionality" to such a degree that "the black body alone continues to shimmer with the aura of presence." Monáe is well aware that, as she sings in her biggest hit to date, she must "tip on the tightrope" of a cultural logic of late capitalism that dictates the impossibility of "the positioning of the cultural act outside the massive Being of capital." She must achieve a "balance" that permits her not to embody anything essential or stable, yet at the same time to address what Dubey terms the "realities of material suffering" for the "have-nots" that Monáe has stated she envisions as her audience. ${ }^{9}$ As the "Wondamix" of that hit, "Tightrope," proclaims: "I'm gonna keep it in the middle so my people can know." 10

From the start of her recording career, Monáe has foregrounded the contingency of the human, particularly of the black female body, through a narrative arc about an imagined android alter ego. Monáe believes the production of such humanoid others represents our inevitable future. In her words: 
It'll happen - there'll be a point where the android's brain will have mapped out that of a human's, and their knowledge will have surpassed that of ours. And we won't be able to differentiate the speaking voice of an android from an actual human's. I do believe that that will be true, because of the rapid speed of technology and nanotechnology advancing. ... I know that we will live in this world. ${ }^{11}$

On her first major recording, the post-apocalyptic 2008 EP Metropolis, set in the year 2719, Monáe introduced Cindi Mayweather as "Android No. 57821, an Alpha Platinum 9000," whose "programming includes a rock-star proficiency package and a working soul." 12 The liner notes explain that, because of her forbidden love affair with a human, Mayweather is being hotly pursued by the evil leaders of the last remaining city on Earth; she had already been an outlaw because of her leadership of a rebel android movement and her creation of "a rebellious new form of pop music known as cybersoul."13

Like her alter ego, Monáe herself has created a new form of music, as well as performance, that critics have found difficult to categorize. One described Monáe as mixing "the dance moves of Michael Jackson, the vocal agility that challenges Aretha Franklin, and the conceptual freakiness of early David Bowie." ${ }^{14}$ The Bowie comparison points to Monáe's (to a degree) androgynous persona, with black-and-white tuxedo and wingtips her signature outfit. Another critic located her performances at "the intersection of cool and classic, somewhere between sci-fi cinema soundtrack, Broadway and Motown's golden era; Monáe's überunique sound and out-of-this-world stage presence shape a presentation that's like peeking into the future." ${ }^{\prime 5}$ As of her second album, the 2010 The ArchAndroid, the liner notes tell us that Janelle Monáe herself has been sent back to our time from the year 2719, where she was cloned into android form as Cindi Mayweather. Mayweather in 2719 has become a "famous android," the ArchAndroid, with a mission to "free the citizens of Metropolis from the Great Divide, a secret society which has been using time travel to suppress freedom and love through the ages." 16

The parallels with the Afrofuturism of Sun Ra, George Clinton, and Lee "Scratch" Perry in the 1960s and 1970s here are clear. All three earlier figures also claimed to be from outer space and other times, sent back to save black people on Earth. Monae has even started to call her band the "ArchOrchestra," presumably an allusion, and perhaps an homage, to Sun Ra's "Arkestra." ${ }^{17}$ But the similarities between Monáe/Mayweather and Clinton/P-Funk (the name for the combined Parliament and Funkadelic groups, or for "Pure-funk") are even clearer. Clinton, along with what funk scholar Rickey Vincent refers to as the "P-Funk Mob" (an ever-shifting cast of dozens of generally eccentric players), created an astonishing, if relatively loose, narrative - also across multiple albums - about wildly costumed futuristic characters such as the space travelers Dr. Funkenstein and Star Child and Sir Nose D’voidoffunk, their nemesis 
and the antidance embodiment of unfunkiness. ${ }^{18}$ Similarly, Monáe/Mayweather and her band and dancers contended with black-cloaked, faceless antidance figures in her official "Tightrope" video and in her 2011 stage performances. ${ }^{19}$ However, quite unlike Clinton and Parliament/Funkadelic, Monáe, who radically blends musical genres, does not specialize in "uncut funk," as sung of in perhaps the greatest funk song ever, "P-Funk, Wants to Get Funked Up," from Mothership Connection.

With its steady 4/4 time signature and driving beat, "P-Funk" epitomizes 1970s funk. Both the lead singer, Clinton himself, and the chorus sing: "I want my funk uncut," with all the connotations of "uncut" as intact as the funk itself. ${ }^{20}$ Pure, black, beat-heavy, and decidedly masculine, this is funk presided over by the men in the band and backed up by the women in the chorus. Clinton asks, "Can you imagine Doobie [Brothers] in your funk?"21 Of course not! This is uncut funk. In the second cut on the album, "Starchild," we are assured that "If you hear any noise, / it's just me and the boys. / . . / You got to get in the band." 22 This is call-and-response funk with Afrocentric, masculinist, and messianic overtones, and with no funkstresses in sight. Even as partisan a funk expert as Rickey Vincent acknowledges that "[f]or all its universality and freedom, funk and the era of black bands were still a movement led by black men." ${ }^{23}$ Ice Cube has confirmed that more recently: "My uncle Jerry was a DJ and introduced me to all the P-Funk records when I was a little kid: The Clones of Dr. Funkenstein, Mothership Connection. I loved them because they reminded me of cartoons, but they were crazy and psychedelic, and the superheroes were black men." ${ }^{24}$ Listeners are invited to join in with these male superheroes, or "recording angels," as the song terms them: "Ain't nothing but a party y'all." ${ }^{25}$ For the most part, the album focuses on a male-hosted party, on "me and the boys" forging a connection between their audience and themselves and the mothership, an alternative space and time for unadulterated (uncut) blackness and black joy, wherein multiple forms of black music, even sorrow songs, become newly funked up: "swing down, sweet chariot, and let me ride."26

Yet there were more layers musically and politically - and even in terms of gender-to Clinton and P-Funk's funk, including their most popular party tunes. P-Funk blended psychedelic rock with funk and, as Vincent points out, ended up synthesizing "European chord structure and African rhythms into a large, ensemble sound." 27 Just as important, as J. Griffin Rollefson observes, "Parliament produces its P-Funk by hyper-amplifying, cloning, and otherwise electronically replicating the funk." 28 Vincent goes so far as to assert that PFunk "introduced the electronic age into modern black music," perhaps most famously with the Moog-synthesized, multilayered bass line that incomparable keyboardist Bernie Worrell invented and that drove P-Funk's biggest hit, the 1978 "Flashlight." ${ }^{29}$ Likewise, behind the steady 4/4 funk beat on "Starchild," we can hear at times a soaring, synthesized keyboard melody - a distinct, sonic narrative of ascension that renders the Mothership more than just a funky Earth party. Clinton and P-Funk also at times strayed from, or at least supplemented, a 
funk beat, the "on the one" Clinton famously called out to band and to audience in a confirmation of both musical rhythm and racial solidarity. For example, at the end of "P-Funk," a jazz piano riff soars upward behind the funk beat.

Far from being "gratuitous," as Mark Anthony Neal has suggested, PFunk's signature combination of funk and jazz with electronic sounds edges their musical playfulness toward political commentary, toward a diagnosis and a cure of social ills through multilevel musical form and lyrics that, together, predict ever greater and equally multilevel black power in the future. ${ }^{30}$ Their 1976 classic "Chocolate City" represents one of P-Funk's most overt futuristic political funk statements, as it imagines that "[Muhammed] Ali is in the White House . . And Miss Aretha Franklin [is] the First Lady." ${ }^{\prime 31}$ For their black listeners, P-Funk offers a kind of funk-faith healing for the times: If you have "faults, defects or shortcomings," you can "lay it on the radio," because "funk not only moves, it can remove." ${ }^{32}$ Their funk was in the business of removing African Americans from Earth in a bleak post-Black Power, post-Civil Rights Movement, and post-Watergate era, and of removing African American men from the constraints of popular 1960s and early 1970s constructions of black masculinity. There were no berets, no pastor's collars, no long leather coats, and no pimp suits in evidence on the Mothership. Rather, Parliament's album covers and concerts represented outrageous and intentionally unsettling versions of black masculinity - from George Clinton's slinky stage moves, to vocalistguitarist Garry Shider's infamous diaper wearing and pacifier sucking, and to bassist-vocalist Bootsy Collins's funky-couture spangled hats and suits and signature star-shaped sunglasses.

But while these performances and costumes certainly stretched notions of the black masculine, they neither addressed nor transformed the black feminine. The tune "Handcuffs" on Mothership Connection - "Do I have to put my handcuffs on ya mama?" or do "I have to keep you barefoot and pregnant / . . . to keep you in my world?"- -imagines literal restraints, even though the singer knows "that's not the way it should be," in order to hold on to his woman in the context of 1970s feminism (the singer says he doesn't worry about being called "some kinda chauvinistic whatever"). ${ }^{33}$ On stage, one of P-Funk's backup singers actually wore as a costume an exaggerated form of a chastity belt, another possible restraint the singer in "Handcuffs" considers. Granted, both song and singer deliver the lyrics in a playful, even resigned fashion. Everyone seems to know that it's past time to try to restrain or contain women. Still, although both Clinton and P-Funk might have been performing black masculinity in a relatively unrestrained way, neither black femininity nor an underlying gender binary got an especially new ride on the Mothership.

By contrast, Janelle Monáe's tuxedo and her Cindi Mayweather personaboth of which she has sustained from the 2008 Metropolis EP, to the 2010 album The Archandroid, and to the 2013 album Electric Lady — suggest an androgyny and a general fluidity of identity that exceed P-Funk's gender play. ${ }^{34} \mathrm{In}$ a 2010 interview with Jet magazine, Monáe said, "I don't believe in menswear 
and women's wear. I just like what I like and I want to be respected as an individual. I think it's time for someone . . . to help redefine what a woman can wear, how she can dress and wear her hair." 35 Monáe is consistently self-aware of her own performative, as well as sartorial, expansion of womanhood. On her collaborative remix of "Tightrope" with B.O.B. and Lupe Fiasco, she claims, "I can bomb with the fellas / And rock a stage a cappella. . . . Talkin' bout 'why don't she change her clothes?' / Well they ain't seem to mind the last three times I posed in Vogue." 36

Monáe's Cindi Mayweather alter ego is, likewise, visually gendered as female (as we can see by the cover of Metropolis) while nonetheless moving well beyond the normative feminine. Indeed, Mayweather, at least initially, seems to match Donna Haraway's classic theorizing of the cyborg as "a creature in a post-gender world . . . resolutely committed to partiality, irony, intimacy, . . . and completely without innocence." ${ }^{37}$ Haraway concludes that cyborgs "are monstrous and illegitimate; [and] in our present political circumstances, we could hardly hope for more potent myths for resistance and recoupling." ${ }^{38}$ In other words, they offer a way out of binaries and solid identities, a path to utter contingency and fluidity of the subject. Just so, as we see in the official video for "Many Moons" from Metropolis, Cindi Mayweather can, with the flip of a switch, transform from white - a kind of inhuman, robotic ultra-whitenessto human-seeming black. ${ }^{39}$ She then takes the stage to perform her cybersoul as part of an android-auction/fashion show, where she garners immense bids from a motley collection of creepy, futuristic spectators. This remarkable color transformation and subsequent performance correspond well to an ironic awareness of the monstrousness of racial constructions and racialized economies of desire, including within the music industry (some of the bidding spectators are played by Monáe's musical collaborators; for example, Deep Cotton). However, Monáe's android is also analogized in this video to a quite specific identity — not only a fashion model but also a black female slave on the auction block.

Contingency and fluidity of identity thus cannot be sustained even in this futuristic context. There is no postrace or postgender either now or in the 2719 world of androids. Near the end of the film, Monáe/Mayweather, in spoken voice over the music, offers an incantation of still more specific identities and conditions in what the liner notes for Metropolis term a "Cybernetic Chantdown" - that is, a spoken word catalog mostly of stereotypes of black women, followed by a number of references to Monáe's own identity: “crack whore, closet drunk, black girl, bad hair," then "tuxedo, outcast" (referencing her own costume and others of her musical collaborators, Big Boi and Andre 3000 of OutKast). ${ }^{40}$ The video ends with the android's elevation, at first suggesting freedom through escape, perhaps on a kind of Mothership, but in the end looking a lot more like deactivation. Cindi Mayweather, whose very name combines sunny spring and the possibility of death (she "may" or may not "weather" her trials), similarly combines the notion of freedom achieved through the tech- 
nological with the notion of robot as the ultimate, malleable "other," perpetually subject to domination and to fetishization within commodity culture and to reinsertion into familiar social categories and identities, from gentlewomanequestrian to bride, as in the "Many Moons" video.

Yet even as she expresses skepticism about the postracial, the postgender, and the posthuman as avenues to freedom, Monáe/Mayweather tempers that pessimism with optimism regarding the potentialities of the technological. "Revolutionize your lives and find a way out," she sings in "Many Moons," while she challenges us not to "keep on blaming the machine" in "Tightrope." So Monáe tips on the tightrope once again, at times supporting and enacting Alexander Weheliye's notion that black performers can deploy technology to obviate the trap of African American embodiment that Dubey warned against. In his analysis of DJs and vocoder-mediated singing, Weheliye notes that "[i]nstead of pulling the strings in the background - that is, being disembodied - these producers, who plug the performers into the technological apparatus, take front and center stage with the artists. This creates a composite identity, a machine suspended between performer and producer that sounds the smooth flow between humans and machines." ${ }^{\circ 2}$ Weheliye here rightly challenges romantic views of black subjectivity and black music as authentic in direct proportion to their antitechnological, bodily qualities and points precisely toward what Monáe might term the "middle."

Monáe's steady deployment of multimedia and contemporary studio effects (including autotune and synthesized instruments) distinguishes - in much the same way as does her gender play-her music from Parliament's "uncut" 1970s funk. In creating an extensively packaged and sometimes wholly processed musical product, she defies generic labels in favor of a futuristic, blended - that is, a highly "cut" - technological, even commercially oriented, medium. On the one hand, Monáe explicitly strives to unite and pay homage to the working class. As she said in an MTV interview, "I don't make music for kings or queens, I make music for regular people. I wear my black and white uniform to pay homage to those who are working every single day like my mother and father." ${ }^{\wedge 3}$ She nonetheless seems to accept a certain level of corporate participation for example, by selling the rights to her single "Tightrope" for a K-Mart television ad for teen and preteen back-to-school clothing and gear.

Clearly, then, Monáe does not wholly resist either technology or commodification; rather, she sees their deep connection. As Stephen Tumino has recently argued, a techno- or knowledge- economy, what he terms "cyber-capitalism," does not signal a utopian postindustrial, post-Fordist world characterized by creativity and global cooperation. Such neoliberal notions, according to Tumino, simply mask the exploitative nature of the labor that underlies cyber-capitalism, as with all capitalist formations. ${ }^{44}$ Just so, Monáe's formal reiteration of her technologized identity through frequent voice modulation has its parallel in the commodification of her person. With the wide array of android personas being auctioned in the "Many Moons" video, from "Cindi Mayweather" to "Jane 
Lee" to "Jahnny Money," Monáe (a homonym for money in this context) makes a striking statement that the exploitative nature of commodity culture is both inevitable and inescapable; her cyberpersonas are the very products of such a culture: "I'm a product of metal, product of the man," she sings on Metropolis's "Violet Stars Happy Hunting!" 45 However, Monáe is ultimately more sanguine than Tumino. She also taps commodity culture and technoculture in order to construct alternative identities that can contort or dissolve traditional forms of race and of gender, and, as she sings so often, of love.

Throughout her discography, Monáe cites love as the antithesis to "the man." From the start, her love affair with the human Anthony Greendown provokes her run from the law in Metropolis. In politicizing this forbidden relationship, Monáe implicitly invokes the struggle for interracial marriages of the past and struggles for same-sex marriage in the present. This call to arms in the name of erotic desire calls to mind Claudia Tate's brilliant reading of W. E. B. Du Bois's 1926 essay "Criteria of Negro Art," in which he famously proclaimed, "[A]ll art is propaganda and ever must be, despite the wailing of the purist." 46 Tate recognizes Du Bois's endorsement of art to be a form of politicized desire, or as Du Bois puts it, "I stand in utter shamelessness and say that whatever art I have for writing has been used for propaganda for gaining the right of black folk to love and enjoy." ${ }^{\prime 7}$ One might have expected Du Bois to complete his participial clause with the right of black folk to vote; however, as Tate explains, for Du Bois, the "public satisfaction of racial equality is connected and somewhat analogous to the private pleasure of eroticism, for eros and polity are mutually signifying." ${ }^{48}$ In other words, Du Bois, "rather than invoking the conventional and no doubt expected rhetoric of civil rights to define the objective of his social mission, ... refers instead to libidinal prerogativesindeed, to desire and gratification - to describe the goals of racial activism." ${ }^{49}$

Monáe's track "Locked Inside" from The ArchAndroid renders such an aesthetic-political-racial and libidinal framework explicit: "The color black means it's time to die / And nobody questions why / The writers and the artists, all are paid to tell us lies / . . I can make a change / . . / Father, fill me with desire." ${ }^{50}$ Here it's as if the singer can overcome both thanatos and racism through the eros of culture. In this way, although Mayweather as an android may embody and emerge out of late capitalist modes of production, her music and her relationship with Anthony Greendown nevertheless defy Metropolis's always-already politicized and potentially lethal identity formations (such as those listed in the "Cybernetic Chantdown" at the end of "Many Moons"). The ArchAndroid's wide range of musical genres and modes-from psychedelic ("Mushrooms and Roses"), to classical ("Suite II Overture"), to Simon and Garfunkel-like folk ("Oh Maker"), to Stevie Wonder-influenced pop ("Say You'll Go"), to salsa and other Latin rhythms ("BaBopByeYa"), and, of course, to funk ("Tightrope") — likewise "cuts" across rigid boundaries. Thus Monáe's music, along with her personas and their proclamations of love-to both Anthony Greendown and the listener-“Tell me are you bold enough to reach 
for love?" she sings on "Many Moons"- correspond perfectly to a Du Boisian combination of art and erotics as antioppressive social labor. ${ }^{51}$

At the same time, with this inclusion of us, as listeners, in her narrative of politicized love and her synthesis of sounds, Monáe potentially creates an exceptionally broad and inclusive technocultural community, one that could empower androids and humans alike. Indeed, as Anna Everett has argued, the Internet's "spatial and temporal ruptures" render it "a promising site for the establishment of an egalitarian technosphere," because, she continues, "[n]ot only do national borders increasingly disappear in cyberspace, they are replaced by new kinship structures now predicated on the fluidity of cybernetic virtual communities and homelands," what Monáe and her fellow artists might term a Wondaland.$^{52}$ And all of us, but particularly African American women and girls, are invited to Wondaland. Consistently, Monáe addresses her listeners: "Daydreamers please wake up / We can't sleep no more" and "When you take off your clothes / All your dreams go down the drain, girl" on "Sincerely Jane" from Metropolis; "The droid control will take your soul and rate it / Berate it, slay it" on "Neon Valley Street" and "Your magic mind makes love to mine" on "Wondaland" from The ArchAndroid. ${ }^{53}$ And although "Sincerely Jane" directly addresses young black women, songs like the highly vocally modulated and synthesized "Wondaland" call upon all listeners to imagine Everett's "egalitarian technosphere"- "This is your land / Hallelujah / This is my land / Hallelujah"- even if such a Wondaland may be rife with contradictions. ${ }^{54}$ As Monáe and her chorus of android clones sing on "Many Moons," "You're free but in your mind / your freedom's in a bind." 55

Monáe portrays Cindi Mayweather in just such a state of constant paradoxical tension. The android seemingly functions as a revolutionary figure, but one who alternately resists and embraces "the man." Throughout Monáe's discography, we are clearly supposed to root for Cindi Mayweather; she is the mediator between not only androids and humans in Metropolis but also between the future and our own time. In this, she is quite unlike the female robot in Lang's film Metropolis, the monstrous expression of an unchecked and evil alliance between industrial capital and technological innovation. As Lawrence Bird puts it, "In Lang's Metropolis the happy resolution is predicated on the elimination of otherness, as embodied in ... the female robot." ${ }^{56}$ By contrast, the real woman and labor leader in the 1927 Metropolis, Maria, provides the means for that resolution. She is "the mediator between heart and head," with labor being the heart and capital/owner of the means of production being the head. But in Monáe's late capitalist world, the android-other takes the human woman's place not only as a mediator but also as a critic of an updated version of Metropolis. ${ }^{57}$

Monáe/Mayweather's paradoxical existence - one that treads a delicate balance between endorsing and condemning capitalism - is perhaps no more apparent than on Metropolis's fourth track, "Cybertronic Purgatory." The most ethereal song on the EP, the song documents Mayweather's deactivated, floating state after a traumatic end at the auction in "Many Moons" (when a soul or 
spirit seems to soar out of the android's body), as well as her youth and vulnerability to the desires and bids of the auction's spectators. "Cybertronic Purgatory" is also among the most highly technologized of her tracks. Monáe's voice, which can easily reach these high-register notes without synthesized effects (such effects are notably absent in her live performances), soars over light guitar with autotune and voice modulations, while the lyrics signal confusion and fear: "Me lost too / Sorry I'm in a maze." "58 As Bird notes, the maze is a central image and part of the set in Lang's Metropolis as well: "While the Metropolis of Lang's film is structured around the New Tower of Babel, it also offers a labyrinth: twisting passages and catacombs beneath the city, at once spaces of danger, secrecy, and safety. Yet even as these labyrinthine structures appear to unravel the vertical authority of the city, they are inseparable from it." 59

Just so, while she flees capture at the hands of those controlling the Metropolis of the future, Mayweather also acknowledges her fragile status as the other produced by, and inseparable from, their authority. On the track "Violet Stars Happy Hunting!" she sings, "I'm a cyber girl without a face a heart or a mind" while robotic voices chant in the background. As Mayweather freestyles without lyrics for a short five seconds, these clones continue chanting until the final full — and loudest — statement: "I'm a product of the man." This free singing occurs only once amid these sustained chants, reinforcing the omnipresence of a cyber-capitalism that is keeping our "freedom in a bind. ${ }^{\circ 60}$ But once again, Monáe does not give up the "hope" that Tumino, for one, utterly rejects, as he punctures the notion that " "now' is the time of creative self-expression and a newfound freedom," arguing instead that "this familiar story . . . hides beyond it the material inequality in production that actually explains culture and its differences and conflicts, which [are] caused by unequal access to material resources such as energy, housing, food, health care, and communications." ${ }^{\prime 61}$ What Tumino leaves out of his dire picture is an audience. In forging a cybernation with which to interact, Monáe aims to empower the listener and convey the power of cyberidentity to subvert the oppressive powers of Metropolis. The reassuring lines "And when the world just treats you wrong, / Just come with with us and we'll take you home" end "Many Moons." 62

With her imagination of androids as the new, mediating others who are, in Haraway's words, "committed to building a political form that actually manages to hold together" disparate constituencies "long enough to disarm the state," Monáe is quick to distinguish between fantasy and futurism. ${ }^{63}$ She sings of an apparently fictional setting and city, Metropolis, in both her 2008 EP of the same name and her 2010 full-length album, The ArchAndroid, yet this visionary world - and by extension, Wondaland in The Archandroid - while decidedly futuristic, is nonetheless quite real. In other words, Wondaland may represent an imagined future, better world to be inhabited by humans and androids alike, on equal footing. But it also represents two tangible, and likewise egalitarian, present-day realities: the artists' collective of Wondaland Arts Society and the aesthetic (and political) experiences shared by Monáe and her audiences. 
Monáe croons on the upbeat, techno-funky "Wondaland" track, "You can go, but you mustn't tell a soul / There's a world inside / Where dreamers meet each other. ${ }^{{ }^{6} 4}$ In this sense, then, Wondaland exists in much the same way that Parliament's Mothership Connection does. Both represent an imagined other space, as well as a tangible populated space that does away with racial oppression and the most oppressive aspects of consumer culture. For Monáe, however, this space is always complicated by her status as the commodified other, one who is conscious of that status and of the impossibility of decommodification, because it would in turn necessitate deactivation.

George Clinton, too, struggled with commodity culture, but rather than "tip on the tightrope," he leaned toward unalloyed resistance from a position outside that culture, precisely the position that Jameson argues cannot exist in postmodernism. For example, the "Funkentelechy" track on Parliament's 1977 album Funkentelechy vs. The Placebo Syndrome offers an extended parody of commercial slogans and jingles as a means to diagnose the ills of commodity culture: "When you're taking every kind of pill / (You deserve a break today) / Nothing seems to ever cure your ill / (Have it your way)." Funk, the real cure, they sing, "is a non-profit organization." ${ }^{\prime 5}$ Yet Clinton, too, ended up doing a commercial - and for Burger King, of all companies ("have it your way" was the chain's primary slogan in the mid-1970s). As Touré observes in a 1993 Rolling Stone profile, in 1978 Clinton created "his conceptual masterpiece One Nation under a Groove, posing funk itself as a nationalistic political Party." ${ }_{66}$ But as of the 1980s both parties - the political and the social — seemed to be over for Clinton and P-Funk. In Touré's words:

1980 stopped Clinton cold. In the greed decade, Clinton produced only one song, "Atomic Dog," as popular and important as his 1970s funk. He had to declare bankruptcy and, worse, was forced to film the Burger King commercial. But, to Clinton, it was all about surviving. "If a mother had to ho in 'Cosmic Slop' to take care of her children," he asks, "you think I wouldn't eat a motherfucking hamburger?"67

Clinton is referring to the "Cosmic Slop" cut on Funkadelic's 1973 album of the same name, which is sung from the perspective of a son whose mother "was well known through the ghetto / Tricks would come and then they'd go." 68 Clinton's analogizing his commercial capitulation to prostitution may seem extreme, but it must be understood in the context of the structure of the popular music industry of the 1960s-1980s. Despite an increase in the influence of black DJs and the sheer marketability of black music in these decades, "the real power [in the recording industry] had not changed hands," as Rickey Vincent puts it. ${ }^{69}$ By the mid-1970s, Mark Anthony Neal explains, "much of the black popular music tradition had been successfully annexed by a small cadre of entertainment conglomerates. ${ }^{, 70}$ Being an independent black funk artist within a 
white-dominated, disco-driven late 1970 s and early 1980 s music industry simply was not possible.

Janelle Monáe, by contrast, released her first recording independently and then was signed by Sean Combs and Bad Boy Records for her first CD. When asked by an interviewer whether she had been worried about signing with a major label, Monáe replied:

Oh, absolutely. I remember doing a couple showcases early on and, in the back of my mind, I knew that we didn't have to have a middle man. That's when I started the Wondaland Arts Society, which includes screenwriters, illustrators, performance artists. It's like an orphanage for artists who come into town, from Of Montreal's Kevin Barnes to Saul Williams. ${ }^{71}$

Of her signing with Combs, she said, "So we formed a partnership. It's not a direct signing — creatively and monetarily, we control things." 72 Monáe has thus effectively positioned herself as the primary creative and controlling force behind all her work. Although she certainly collaborates with other musicians, artists, and performers, especially those in Wondaland, she composes her music, writes her lyrics, directs production, and conducts negotiations with her label. In embracing her role as the mediator between artist and label, between androgyny and Vogue, between androids and humans, between capital (the haves) and the working class (the have-nots), and between technoculture and live performance, Monáe creates a sound and persona that are far more feminist, as well as more willingly commercial and more self-consciously amalgamated, than were George Clinton and P-Funk and their uncut funk.

We should not forget, however, that her narrative - complete with futuristic alter ego, space, and time travel, and gender play-owes a great deal to Clinton and P-Funk, itself an artist's collective of its time. Indeed, contemporary popular African American music in general, especially hip hop, would be hard to imagine without the influence of P-Funk. As Clinton observes, "We were keeping track of how many people'd sampled us, but I stopped at around 2,000 songs." 73 Monáe and Wondaland, Sean Combs and Bad Boy Records, DJ Spooky and his collective Soundlab, and Dr. Dre with his G-Funk and Death Row Records (and later Aftermath Entertainment), among plenty of others, together represent and manage distinct spaces within "a black-music world built on Clintonian concepts," to use Touré's words. ${ }^{74}$

That world may in fact be more coherent and more diverse-as well as more digital - than was P-Funk's, but that is only because it is now possible to make and hear "cut" funk and to want it that way. Indeed, it may be that Monáe and her compatriots are poised to "afford us some glimpse into a postmodern or technological sublime," a sublime that Jameson posits then immediately dismisses, given "the whole world system of present-day multinational capitalism."75 Janelle Monáe's and Wondaland's new, multivalent version of Afrofu- 
turism, that is, neo-Afrofuturism - expressed via highly technologized music and vocals, dance, website manifestos and blogs, interviews, clothing, videos, extraordinarily dynamic live performances, and even commercials - provides us with a fresh, funky optimism that promises not so much to "remove" as to move us, even in the context of contemporary capitalism. Monáe has no plans to leave the planet.

\section{Notes}

1. Paul D. Miller, The Book of Ice (Brooklyn, NY: Mark Batty, 2011), 122.

2. Pete Lewis, "Janelle Monáe: Funky Sensation," Blues \& Soul Music Online 1054 (2010), http://www.bluesandsoul.com/feature/554/janelle_monae_funky_sensation.

3. Janelle Monáe, liner notes, Metropolis (Bad Boy Records, 2008).

4. Wondaland Arts Society, http://www.wondaland.com/about.

5. Parliament, "Star Child," Mothership Connection (Casablanca Records, 1975).

6. Wondaland Arts Society, http://www.wondaland.com/about.

7. Madhu Dubey, Signs and Cities: Black Literary Postmodernism (Chicago: University of Chicago Press, 2003), 8.

8. Fredric Jameson, Postmodernism, or, the Cultural Logic of Late Capitalism (Durham, NC: Duke University Press, 1991), 48.

9. Dubey, Signs and Cities, 9; Seth Colter Walls, "Pop Goes the Art House," Newsweek 155, no. 23 (June 7, 2010): 52.

10. Janelle Monáe, "Tightrope (Wondamix) [Feat. B.o.B. and Lupe Fiasco]." http://youtu. be/_GlpeFqMLZI, 2:21-2:23.

11. Gillian "Gus" Andrews, interview, "Janelle Monaé Turns Rhythm and Blues into Science Fiction," io9 (July 21, 2010), http://io9.com/5592174.

12. Monáe, liner notes, Metropolis.

13. Ibid.

14. Cindi Filipenko, review, Janelle Monáe, The ArchAndroid, "Femmes De Chez Nous," Herizons 25, no. 1 (2011): 36.

15. E.W., "Janelle Monáe, The Game Changer," Ebony 65, no. 10 (2010): 75.

16. Janelle Monáe, liner notes, The ArchAndroid (Bad Boy Records, 2010).

17. Janelle Monáe, "Euro Tour: 07.03.11 Roskilde, Denmark," http://youtu.be/ em0Af7nW5k4, 0:04-0:06.

18. Rickey Vincent, Funk: The Music, the People, and the Rhythm of the One (New York: St. Martin's Press, 1996), 231.

19. Janelle Monáe, “Tightrope [feat. Big Boi]," http://youtu.be/pwnefUaKCbc, 4:13-4:38; Janelle Monáe, "Bruno Mars \& Janelle Monae: Hooligans in Wondaland Tour," Roy Wilkins Auditorium, St. Paul, MN, May 25, 2011.

20. Parliament, "P-Funk (Wants to Get Funked Up)," Mothership Connection (Casablanca Records, 1975).

21. Ibid.

22. Parliament, "Star Child."

23. Vincent, Funk, 99; emphasis in original.

24. Ice Cube and Olaf Hajek, "Parliament/Funkadelic," Rolling Stone 972 (April 21, 2005): 60.

25. Parliament, "Star Child."

26. Ibid.

27. Vincent, Funk, 231.

28. J. Griffith Rollefson, "The "Robot Voodoo Power" Thesis: Afrofuturism and Anti-AntiEssentialism from Sun Ra to Kool Keith," Black Music Research Journal 28, no. 1 (2008): 100.

29. Vincent, Funk, 244, 246.

30. Mark Anthony Neal, What the Music Said: Black Popular Music and Black Public Culture (New York: Routledge, 1999), 103.

31. Parliament, "Chocolate City," Chocolate City (Casablanca Records, 1975).

32. Parliament, "P-Funk."

33. Parliament, "Handcuffs," Mothership Connection (Casablanca Records, 1975).

34. Electric Lady had just been released as this essay was going to press.

35. Melody K. Hoffmann, "Janelle Monáe: Brave, Bold, Fearless," Jet 118, no. 5 (August 2, 2010): 32 .

36. Monáe, "Tightrope (Wondamix)."

37. Donna J. Haraway, Simians, Cyborgs and Women: The Reinvention of Nature (New York: Routledge, 1991), 150-51. 


\section{Daylanne K. English and Alvin Kim}

38. Ibid., 154.

39. Janelle Monáe, Many Moons [Official Short Film]. http://youtu.be/LHgbzNHVg0c, $0: 35-0: 37$.

40. Monáe, liner notes, Metropolis; Monáe, Many Moons.

41. Janelle Monáe, "Many Moons," Metropolis (Bad Boy Records, 2008); Janelle Monáe, "Tightrope," The ArchAndroid (Bad Boy Records, 2010).

42. Alexander G. Weheliye, "'Feenin': Posthuman Voices in Contemporary Black Popular Music," Social Text 20, no. 2 (2002): 31.

43. Joseph Patterson, “Janelle Monáe: The Interview!” MTV UK (May 12, 2010), http:// www.mtv.co.uk/music/urban/221695-janelle-monae-the-interview.

44. Stephen Tumino, Cultural Theory after the Contemporary (New York: Palgrave Macmillan, 2011), 20.

45. Janelle Monáe, "Violet Stars Happy Hunting!” Metropolis (Bad Boy Records, 2008).

46. W. E. B. Du Bois, "Criteria of Negro Art," Crisis 32 (October 1926): 296.

47. Ibid.

48. Claudia Tate, Psychoanalysis and Black Novels: Desire and the Protocols of Race (New York: Oxford University Press, 1998), 49.

49. Ibid., 48.

50. Janelle Monáe, "Locked Inside," The ArchAndroid (Bad Boy Records, 2010).

51. Monáe, "Many Moons," Metropolis.

52. Anna Everett, "The Revolution Will Be Digitized: Afrocentricity and the Digital Public Sphere," Social Text 20, no. 2 (2002): 130, 138.

53. Janelle Monáe, "Sincerely Jane," Metropolis; Monáe, "Neon Valley Street," The ArchAndroid; Monáe, "Wondaland," The ArchAndroid.

54. Monáe, "Wondaland."

55. Monáe, "Many Moons," Metropolis.

56. Lawrence Bird, "States of Emergency: Urban Space and the Robotic Body in the Metropolis Tales," Mechademia 3 (2008): 132.

57. Metropolis, dir. Fritz Lang (1927), DVD (Kino Video, 2002).

58. Monáe, "Cybertronic Purgatory," Metropolis.

59. Bird, "States of Emergency," 131.

60. Monáe, "Violet Stars Happy Hunting!"

61. Tumino, Cultural Theory, 21.

62. Monáe, "Many Moons."

63. Haraway, Simians, Cyborgs, and Women, 155.

64. Monáe, "Wondaland."

65. Parliament, "Funkentelechy," Funkentelechy vs. The Placebo Syndrome (Casablanca Records, 1977)

66. Touré, “Clinton's Health Plan: More Funk 4 U,” Rolling Stone 669 (November 11, 1993): 11.

67. Ibid.

68. Funkadelic, "Cosmic Slop," Cosmic Slop (Westbound Records, 1973).

69. Vincent, Funk, 156.

70. Neal, What the Music Said, 102.

71. Ryan Dombal, "Janelle Monae Talks Robots, Diddy, and Her Genre-Bursting New Album," Pitchfork (May 17, 2010), http://pitchfork.com/news/38754-janelle-monae-talks-robotsdiddy-and-her-genre-bursting-new-album.
72. Ibid.
73. Quoted in Touré, "Clinton's Health Plan," 11.
74. Touré, "Clinton's Health Plan," 11.
75. Jameson, Postmodernism, 37. 